\title{
PENGARUH LATIHAN PEREGANGAN STATIS TERHADAP FLEKSIBILITAS PADA MAHASISWA PENGHOBI FUTSAL OFFERING A ANGKATAN 2014 JURUSAN ILMU KEOLAHRAGAAN FAKULTAS ILMU KEOLAHRAGAAN UNIVERSITAS NEGERI MALANG
}

\author{
Rohmat Ainul Yaqin \\ Olivia Andiana, S.Or. M.Kes \\ dr. Rias Gesang Kinanti, M.Kes \\ Email: rohmatainulyaqin030996@gmail.com, Olivia a3@yahoo.co.id, \\ riaskinanti@yahoo.com \\ Jurusan IImu Keolahragaan Fakultas IImu Keolahragaan Universitas Negeri Malang
}

\begin{abstract}
Flexibility is the ability of muscle tissue extend to the maximum until the scope of the full joint motion without any pain. Futsal sport in much-needed flexbility to avoid the risk of injury. But, the fleksibility of a person can be enchanced through stretching exercise. One of static stretching is the stretching exercise. This research aims to know the influence of static stretching exercise against the flexibility. This research uses the pre-post test method. The samples in this study are students sports science hobbyists futsal in the Faculty of Sports Science offering A 2014 with a total of 10 people. Before taking the samplendata are given instructions for performing the test flexibility. After doing static stretching exercise for 6 weeks back taken test through flexibility. Tools used in this study is flexometer. The results of the data then conducted a test of normality pre-post tes and then test results data paired sample T-Test. The results showed that the mean of the measurements of flexibility before doing static stretching exercise $1 \mathrm{~cm}$, while after doing static stretching exercise for 6 weeks showed results $7,2 \mathrm{~cm}$. Test result data paired sample T-Test show results pre-test and post-test on the test result is flexibility value Asymp. Sig. (2-tailed) that is equal 0,000, smaller than a=0,05. The result is smaller than in $a=0,05$ this significant research data.
\end{abstract}

Keyword: Flexibility, Static Stretching, Futsal.

ABSTRAK: Fleksibilitas merupakan kemampuan jaringan otot memanjang secara maksimal hingga lingkup gerak sendi penuh tanpa ada rasa nyeri. Dalam cabang olahraga futsal fleksibilitas sangat dibutuhkan agar terhindar dari resiko cedera. Namun fleksibilitas seseorang dapat ditingkatkan melalui latihan peregangan. Salah satu latihan peregangan adalah peregangan statis. Penelitian ini bertujuan untuk mengetahui pengaruh latihan peregangan statis terhadap fleksibilitas. Penelitian ini menggunakan metode pre-post tes. Sampel pada penelitian ini adalah mahasiswa penghobi futsal Jurusan IImu Keolahragaan Offering A 2014 dengan jumlah 10 orang. Sebelum pengambilan data sample diberi arahan untuk melakukan tes fleksibilitas. Setelah melakukan latihan peregangan statis selama 6 minggu sampel kembali diambil data melalui tes fleksibilitas. Alat digunakan dalam penelitian ini adalah flexometer. Hasil data kemudian dilakukan uji normalitas pre-post tes dan kemudian hasil uji data paired sample $T$-Test. Hasil penelitian menunjukan bahwa mean dari pengukuran fleksibilitas sebelum melakukan latihan peregangan statis $1 \mathrm{~cm}$, sedangkan setelah melakukan latihan peregangan statis selama 6 minggu menunjukan hasil $7,2 \mathrm{~cm}$. Hasil uji data paired sample T-Test menunjukan hasil pre-test dan post-test pada tes fleksibilitas hasilnya adalah nilai Asymp. Sig. (2-tailed) yakni sebesar 0,000 , lebih kecil dari pada $\alpha=0,05$. Hasil tersebut lebih kecil dari pada $\alpha=0,05$ sehingga data penelitian signifikan.

Kata Kunci: Fleksibilitas, Peregangan Statis, Futsal

Fleksibilitas merupakan kemampuan jaringan otot memanjang secara maksimal hingga limgkup gerak sendi penuh tanpa rasa nyeri (Wiguna, 
dkk 2016:41). Menurut Norhanani dalam Susilo (2014:13), fleksibilitas adalah kemampuan seseorang untuk dapat melakukan gerak dengan ruang gerak seluas-luasnya dalam persendian. Ada beberapa faktor yang dapat mempengaruhi fleksibilitas seperti persendian, elastis otot, ligamen, bentuk tubuh, jenis kelamin, dan usia (Agustin, 2013:2). Dalam cabang olahraga apapun fleksibilitas sangat diperlukan untuk kebutuhan gerak sehari-hari karena fleksibilitas merupakan fungsi seluruh persendian yang terdapat pada tubuh (llyas, 2016:16). Fleksibilitas sangat dibutuhkan bagi olahragawan ataupun bukan olahragawan, karena semakin fleksibel otot seseorang maka semakin kecil kemungkinan orang tersebut untuk mengalami cedera (Rahmiati, 2013:2). Menurut Alim (2012:13), kemampuan fleksibilitas yang terbatas juga dapat menyebabkan penguasaan teknik yang kurang baik dan prestasi rendah. Dari beberapa kutipan di atas bisa disimpulkan bahwa fleksibilitas dibutuhkan dalam berbagai cabang olahraga terutama olahraga prestasi seperti futsal.

Dalam olahraga futsal, fleksibilitas merupakan salah satu komponen utama karena futsal merupakan olahraga yang dinamis (Abhdany, 2016:1). Futsal merupakan sepak bola yang dimainkan dalam ruangan yang terdiri dari 5 pemain yang disetujui secara resmi oleh FIFA (Costa dkk, 2012:110). Selain 5 pemain utama, setiap regu juga diizinkan memiliki pemain cadangan (Sudibyo, 2013:1). Menurut Hamid (2013:1), tujuan dari futsal adalah memasukkan bola ke gawang lawan dan mencegah terjadinya gol ke gawang sendiri dengan memanipulasi bola dengan kaki. Dalam permainan ini diperlukan kerjasama yang baik dan juga harus didukung dengan teknik, fisik, taktik, dan mental yang bagus agar dapat bermain dengan baik (Pratiwi, 2016:1). Perkembangan futsal di Indonesia mengalami peningkatan beberapa tahun belakangan dengan meningkatnya prestasi tim Nasional futsal Indonesia dikancah Asia. Di Kota Malang sendiri beberapa tahun terakhir juga telah mengalami peningkatan kualitas dalam cabang olahraga futsal. Mulai dari adanya Liga Futsal Malang hingga turnamen-turnamen kecil yang diselenggarakan oleh instansi-instansi di Kota Malang. Menurut Mustaqim (2014:1), popularitas permainan futsal yang semakin meningkat tersebut memungkinkan untuk membina bakatbakat baru untuk menjadi pemain futsal profesional yang dapat berkiprah mengharumkan nama bangsa dikancah internasional.

Cara terbaik untuk meningkatkan fleksibilitas adalah dengan latihan peregangan (Ibrahim dkk, 2015:329). Sama dengan pernyataan (Firdaus dalam Taradita, 2017:3) bahwa latihan yang dapat dilakukan untuk meningkatkan fleksibilitas adalah dengan latihan peregangan. Peregangan adalah latihan fisik yang meregangkan sekumpulan otot agar mendapatkan otot elastis dan nyaman yang biasanya dilakukan sebelum olahraga (Cahyoko dan Sudijandoko, 2016:92. Latihan peregangan dilakukan selama 5-10 menit sebelum melakukan olahraga agar otot merasa lebih rileks dan nyaman (Priono, 2017:12). Peregangan memiliki berbagai manfaat dalam bidang olahraga. Hal tersebut didukung oleh pernyataan Suharjana (2012:42) bahwa salah satu manfaat peregangan sebelum berolahraga dapat mengoptimalkan gerakan, yaitu dengan mengulur otototot, ligamen-ligamen, tendo-tendo, serta persendian. Peregangan dibagi menjadi 3 jenis, yaitu peregangan 
statis, peregangan dinamis, dan peregangan balistik. Salah satu peregangan yang sering dilakukan oleh olahragawan adalah peregangan statis.

Peregangan statis merupakan gerakan penguluran pada otot yang dilakukan perlahan-lahan hingga terjadi ketegangan dan mencapai rasa nyeri atau tidak nyaman pada otot tersebut kemudian dipertahankan pada posisi tersebut (Sugiarto, 2017:3). Dalam penelitian sebelumnya yang dilakukan Suharjana (2013:45) menyatakan bahwa latihan peregangan statis lebih efektif dibandingkan dengan latihan peregangan dinamis dalam hal fleksibilitas. Hal serupa dinyatakan oleh Sullivan, dkk (2009:5) bahwa latihan peregangan statis dapat meningkatkan fleksibilitas otot hamstring yang lebih signifikan daripada peregangan dinamis. Akan tetapi masih banyak penghobi futsal di kota Malang yang masih menggunakan peregangan dinamis sebelum melakukan olahraga futsal.

Tujuan penelitian ini adalah untuk mengetahui pengaruh latihan peregangan statis terhadap fleksibilitas pada mahasiswa penghobi futsal Fakultas IImu Keolahragaan Jurusan IImu Keolahragaan Offering A angkatan 2014 Universitas Negeri Malang.

\section{METODE}

Penelitian ini menggunakan desain penelitian pre-eksperimental dengan one group pretest posttest design yang menggunakan satu kelompok subyek, menggunakan teknik purpose sampling pada 10 mahasiswa penghobi futsal Fakultas IImu Keolahragaan Jurusan IImu Keolahragaan Offering A angkatan 2014 Universitas Negeri Malang.
Pengumpulan data menggunakan tes pengukuran fleksibilitas menggunakan alat flexometer dalam satuan $\mathrm{cm}$. Latihan yang digunakan pada penelitian ini adalah latihan peregangan statis yang dilakukan selama 20-30 menit kemudian sampel dilakukan pengambilan data berupa tes fleksibilitas (Pre-test). Penelitian ini dilakukan selama 6 minggu dan frekuensi latihan 3 kali setiap minggunya. Setelah 6 minggu pemberian latihan peregangan statis, dilakukan pemeriksaan akhir (Posttest) dengan pemeriksaan yang sama seperti pemeriksaan awal yaitu tes fleksibilitas). Analisis data menggunakan uji paired sample t-test dengan bantuan aplikasi SPSS 22 .

\section{HASIL PENELITIAN}

Sampel dalam penelitian ini adalah mahasiswa penghobi futsal Fakultas IImu Keolahragaan Jurusan Ilmu Keolahragaan Offering A angkatan 2014 Universitas Negeri Malang sebanyak 10 orang. Pada penelitian ini responden yang digunakan berusia 20-23 tahun berjenis kelamin laki-laki. Proses pengambilan data penelitian dilaksanakan pada bulan September sampai dengan bulan Oktober 2018. Setelah dilakukan tes fleksibilitas awal (pre-test) pada tanggal 3 September 2018 responden selanjutnya dilaksanakan program latihan peregangan statis. Program latihan peregangan statis dilakukan selama 6 minggu dengan intensitas latihan 3 kali dalam setiap minggunya. Setelah diberi perlakuan dilakukan tes akhir (post-test) sebagai tolak ukur hasil latihan. Tes akhir (post-test) dilaksanakan pada tanggal 18 Oktober 2018. 
Tabel 1. Hasil Tes Fleksibilitas

\begin{tabular}{ccc}
\hline Responden & Pre-Test & Post-Test \\
\hline 1 & $-2 \mathrm{~cm}$ & $7 \mathrm{~cm}$ \\
\hline 2 & $-4 \mathrm{~cm}$ & $9 \mathrm{~cm}$ \\
\hline 3 & $-1 \mathrm{~cm}$ & $6 \mathrm{~cm}$ \\
\hline 4 & $-3 \mathrm{~cm}$ & $6 \mathrm{~cm}$ \\
\hline 5 & $2 \mathrm{~cm}$ & $8 \mathrm{~cm}$ \\
\hline 6 & $8 \mathrm{~cm}$ & $11 \mathrm{~cm}$ \\
\hline 7 & $5 \mathrm{~cm}$ & $8 \mathrm{~cm}$ \\
\hline 8 & $-1 \mathrm{~cm}$ & $2 \mathrm{~cm}$ \\
\hline 9 & $0 \mathrm{~cm}$ & $8 \mathrm{~cm}$ \\
\hline 10 & $-2 \mathrm{~cm}$ & $7 \mathrm{~cm}$
\end{tabular}

Tabel 2. Rata-rata Hasil Tes Fleksibilitas

\begin{tabular}{ccccc}
\hline & Mean & Max & Min & SD \\
\hline Pre-Test & 1.00 & $8 \mathrm{~cm}$ & $-3 \mathrm{~cm}$ & 3,62 \\
\hline Post-Test & 7.20 & $11 \mathrm{~cm}$ & $2 \mathrm{~cm}$ & 2,34 \\
\hline
\end{tabular}

Berdasarkan Tabel 1 dan Tabel 2 menunjukkan bahwa hasil tes fleksibilitas pada saat tes awal (pretest) lebih kecil yakni 1 cmdibandingkan dengan hasil tes fleksibilitas pada saat tes akhir (posttest) yakni $7,2 \mathrm{~cm}$. Dari data tersebut dapat dilihat perbedaan waktu hasil tes fleksibilitas disimpulkan peningkatan sehingga bahwa terdapat fleksibilitas pada mahasiswa penghobi futsal Fakultas IImu Keolahragaan Jurusan IImu Keolahragaan Offering A angkatan 2014 Universitas Negeri Malang

Tabel 3. Hasil Uji Normalitas Data Tes Fleksibilitas Sebelum perlakuan dan sesudah Perlakuan (Pre-Test dan Post-Test)

\begin{tabular}{cccc}
\hline \multicolumn{4}{c}{ Shapiro-Wilk } \\
\\
\hline Statistic & Df & sig. \\
\hline Pre-test &, 901 & 10 &, 222 \\
\hline Post-test &, 916 & 10 &, 328 \\
\hline
\end{tabular}

Berdasarkan Tabel 3 uji normalitas data hasil penelitian dengan dibantu software komputer yakni SPSS 22. Output pada uji normalitas tes fleksibilitas awal (pre-test) menunjukkan Shapiro-Wilk pada pretest hasilnya adalah 0,222 dan hasil dari post-test yakni 0,328 kedua hasil tersebut lebih besar dari $\alpha=0,05$. Maka dapat disimpulkan bahwa data pre-test dan post-test berdistribusi normal. Dari uji normalitas kedua data diatas yang berdistribusi normal maka uji hipotesis yang dilakukan adalah Paired Sample T-Test. 
Tabel 4. Hasil Uji Data Paired Sample T-Test Tes Fleksibilitas

\begin{tabular}{ll}
\hline & POST_TEST-PRE-TEST \\
\hline $\mathrm{SD}$ & $, 2,57$ \\
\hline Asymp. Sig. (2-tailed) &, 000 \\
\hline
\end{tabular}

Berdasarkan Tabel 4 Hasil data penelitian dihitung menggunakan software komputer yakni SPSS 22 dengan menggunakan Paired Sample T-Test. Hasil dari pre-test dan post-test pada tes fleksibilitas hasilnya adalah nilai Asymp. Sig. (2-tailed) yakni

\section{PEMBAHASAN}

Hasil Penelitian

Berdasarkan hasil penelitian terdapat perbedaan hasil tes fleksibilitas antara pre-test dan posttest yang berarti ada pengaruh peregangan statis terhadap fleksibilitas. Pada tabel 4.2 menunjukan bahwa hasil pre-test sample memiliki tingkat fleksibilitas yang berbeda-beda dan memiliki ratarata $1 \mathrm{~cm}$. Dari hasil tersebut bisa disimpulkan bahwa banyak faktor yang mempengaruhi tingkat fleksibilitas. Setelah sample melakukan latihan peregangan statis yang dilakukan selama 6 minggu dengan latihan 3 kali dalam seminggu terdapat perbedaan tingkat fleksibilitas. Pada tabel 4.2 menunjukan bahwa hasil post-test sample memiliki rata-rata $7,2 \mathrm{~cm}$. Seperti pernyataan Satriya (dalam Umasagi, dkk 2012:9) bahwa dengan melakukan pelatihan secara intensif 68 minggu akan meningkatkan kekuatan, kelentukan, dan daya tahan. Latihan yang baik dan berkelanjutan akan membuat tubuh beradaptasi dengan cepat dan baik, sehingga tubuh akan merasakan hasil latihan yang telah dilaksanakan. Pernyataan hampir serupa juga dinyatakan oleh Nala (dalam Umasugi, dkk 2012:9) Pelatihan yang diberikan untuk pemula sebesar 0,000 , lebih kecil dari pada $\alpha=$ 0,05 . Hasil tersebut lebih kecil dari pada $\alpha=0,05$ sehingga data penelitian signifikan dan hipotesis penelitian diterima.

dalam jangka waktu yang sesuai dengan standart akan memperoleh hasil yang konstan, dimana tubuh dapat beradaptasi dengan pelatihan dan akan menghasilkan peningkatan yang berarti.

Dari hasil diatas bisa disimpulkan bahwa adanya pengaruh peregangan statis terhadap fleksibilitas. Berdasarkan fakta tentang keberhasilan latihan peregangan, penelitian yang dilakukan oleh (Suharjana, 2012:18) menjelaskan bahwa latihan peregangan statis dan peregangan dinamis pada dasarnya merupakan suatu cara untuk meningkatkan fleksibilitas dengan kekurangan dan kelebihannya masingmasing, akan tetapi peregangan statis lebih efektif dibandingkan dengan latihan peregangan dinamis. Hal serupa dinyatakan oleh Sullivan, dkk (2009:5) bahwa latihan peregangan statis dapat meningkatkan fleksibilitas otot hamstring yang lebih signifikan daripada peregangan dinamis.

\section{Pengaruh Peregangan Statis terhadap Fleksibilitas}

Fleksibilitas merupakan salah satu komponen kondisi fisik yang memegang peranan penting bagi olahragawan dam non olahragawan. Dalam cabang olahraga apapun 
fleksibilitas sangat diperlukan untuk kebutuhan gerak sehari-hari karena fleksibilitas merupakan fungsi seluruh persendian yang terdapat pada tubuh (llyas, 2016:16). Fleksibilitas adalah kemampuan dari sebuah sendi, otot dan ligamen di sekitarnya untuk bergerak dengan leluasa dan nyaman dalam ruang gerak maksimal yang diharapkan (Ibrahim dkk, 2015). Fleksibilitas seseorang dipengaruhi oleh banyak faktor seperti sendi, ligamen, tendon, jaringan otot, aktivitas, cedera, dan usia.

Cara terbaik untuk meningkatkan fleksibilitas adalah dengan latihan peregangan (Ibrahim dkk 2015:329). Proses terjadinya fleksibilitas dikarenakan struktur otot yang terdapat pada bagian ujung gumpalan otot dengan fungsi menghubungkan otot dengan tulang sehingga dapat menggerakkan persendian ketika otot berkontraksi (Susilo, 2014:38). Mekanisme peregangan statis menurut Sugiarto (2017:6), pada saat otot terulur maka muscle spindle juga terulur. Muscle spindle adalah suatu reseptor di dalam otot yang berperan menerima rangsangan untuk mendeteksi perubahan panjang serabut otot. Muscle spindle akan melaporkan perubahan panjang dan seberapa cepat perubahan panjang itu terjadi serta memberikan sinyal ke medula spinalis untuk meneruskan informasi ke susunan saraf pusat. Muscle spindle akan memicu stretch reflex, stretch reflex merupakan suatu respon yang tidak disadari berupa kontraksi melalui stimulus dari syarafsyaraf otot yang menyebabkan otot terulur. Salah satu alasan untuk mempertahankan suatu penguluran dalam jangka waktu yang lama adalah pada saat otot dipertahankan pada posisi terulur maka muscle spindle akan terbiasa dengan panjang otot yang baru dan akan mengurangi sinyal tadi. Secara bertahap reseptor stretch akan terlatih untuk memberikan panjang yang lebih besar lagi terhadap otot. Ketika otot di stretch dengan perlahan dan lembut, maka golgi tendon organ akan terstimulasi optimal, sehingga penguluran akan terjadi pada serabut otot serta fascia dimana jumlah sarkomer bertambah dan fascia terulur. Stretch refleks mempunyai dua komponen yaitu komponen statis dan komponen dinamis. Komponen statis ditemukan di sepanjang pada saat otot terulur. Komponen dinamis ditemukan hanya pada akhir saat otot diulur dan responnya menyebabkan perubahan panjang otot yang segera. Alasan yang mendasari stretch refleks mempunyai dua komponen adalah karena terdapat dua serabut otot intrafusal yaitu serabut rantai nuklear yang bertanggung jawab untuk komponen statis dan serabut tas nuklear yang bertanggung jawab untuk komponen dinamis. Respon otot terhadap penguluran pada dasarnya terjadi pada komponen elastik dan tegangan dalam otot meningkat dengan tajam, sarkomer memanjang dan bila hal ini dilakukan terus-menerus otot akan beradaptasi (Sugiarto, 2017:6). Sedangkan ligamen merupakan jaringan ikat yang mengikat atau menghubungkan antara satu tulang dengan tulang yang lain pada persendian (Alcantara, 2013).

Latihan peregangan statis dilakukan dengan meregangkan otot tertentu hingg terasa nyeri dan dipertahankan dalam posisi tersebut selama beberapa detik. Manfaat latihan peregangan yaitu meningkatkan kebugaran fisik dengan cara memperlancar transportasi zatzat yang diperlukan tubuh dan pembuangan sisa-sisa zat yang tidak dipakai oleh tubuh; mengoptimalkan gerakan dengan cara mengulur otototot ligameb, tendo, dan persendian 
sehingga dapat bekerja dengan optimal; meningkatkan relaksasi fisik dengan cara penguluran otot-otot tubuh yang tegang menjadi lebih rileks; mengurangi risiko cedera sendi dan otot karena gerak persendian dan otot menjadi lebih luas dan lebih elastis sehingga kemungkinan terjadinya cedera pada sendi dan otot menjadi kecil (Suharjana dalam Priono, 2017:4).

Penelitian Berdasarkan hasil penelitian di atas dan pendapat para ahli, dapat dinyatakan bahwa latihan peregangan statis mempunyai pengaruh dalam meningkatkan fleksibilitas. Dengan melakukan latihan peregangan statis selama 6 minggu dan dilakukan 3 kali dalam seminggu, peneliti memperoleh data bahwa peningkatan fleksibilitas pada mahasiswa penghobi futsal Jurusan IImu Keolahragaan 2014 Offering A Universitas Negeri Malang dengan hasil yang signifikan.

\section{KESIMPULAN}

Pada penelitian ini dapat disimpulkan bahwa ada pengaruh latihan peregangan statis terhadap fleksibilitas pada Mahasiswa Penghobi Futsal Fakultas IImu Keolahragaan Jurusan IImu Keolahragaan Offering A angkatan 2014. Pada penelitian ini dilakukan latihan peregangan statis selama 6 minggu dengan intensitas latihan 3 kali dalam seminggu yang dilakukan di lapanga A2 Universitas Negeri Malang. Setelah dilakukan pengukuran fleksibilitas di Lab PKO Fakultas IImu keolahragaan Universitas Negeri Malang dengan menggunakan alat flexometer terdapat perbedaan hasil antara hasil pre-test dan hasil post-test yang signifikan.

\section{SARAN}

1. Diharapkan dari hasil penelitian ini dapat memberikan pengetahuan sebagai tambahan ilmu dalam bidang olahraga.

2. Diharapkan setelah membaca penelitian ini dapat diterapkan untuk lalangan atlet maupun non atlet.

3. Diharapkan untuk mahasiswa Fakultas IImu Keolahragaan terutama Jurusan IImu Keolahragaan dapat memahami bahwa pentingnya tingkat fleksibilitas untuk melakukan olahraga agar terhindar dari resiko cedera.

4. Diharapkan peneliti lain atau ilmuwan olahraga yang ingin mengembangkan penelitian yang telah dilakukan, disarankan untuk melakukan penelitian sejenis dengan menggunakan testi lebih banyak lagi dan menambahkan variabel lain yang berkaitkan.

\section{DAFTAR RUJUKAN}

Agustin, D. 2013. Pengaruh Pemberian Autostretching Terhadap Fleksibilitas Otot Hamstring pada Kasus Tightness Hamstring. Naskah Publikasi, Fakultas IImu Kesehatan, Universitas Muhammadiyah Surakarta.

Alim. 2012. Fleksibilitas. Jurnal Latihan Fleksibilitas dengan Metode PNF. 5(8): 1-13.

Ibrahim, R. C., Polii, H., \& Wungouw, $\mathrm{H}$. 2015. Pengaruh Latihan Peregangan Terhadap Fleksibilitas Lansia. Jurnal eBiomedik Vol. 3 No. 1.

llyas, F. R. 2016. Hubungan Antara Fleksibilitas Dengan Delayed Onset Muscle Soreness pada Mahasiswa Ekstrakulikuler Karate Universitas Hasanuddin. 
Universitas Hasanuddin Makassar.

Pratiwi, F. K. J. 2016. Hubungan Minat dan Motivasi dengan Keterampilan Futsal Remaja Putri di Bandar Lampung. Skripsi, Fakultas Keguruan DAN IImu Pendidikan, Universitas Lampung.

Priono, S. B. R. 2017. Pengaruh Latihan Peregangan (Streetching Exercise) Terhadap Nyeri Muskuloskeletal Akibat Kerja pada Petugas Kebersihan di FKIK Universitas Muhammadiyah Yogyakarta. Naskah Publikasi, Fakultas Kedokteran dan IImu Kesehatan, Universitas Muhammadiyah Yogyakarta.

Sudibyo, A. 2013. Survei Tingkat Vo2 Max Anggota Tim Ekstrakulikuler Futsal Putri SMA Di Kota Mojokerto. Jurnal Prestasi Olahraga Vol 1 No. 1.

Sugiarto, A. 2017. Pengaruh Durasi Static Streetching Otot Hamstring Terhadap Peningkatan Ekstensi Sendi Lutut pada Lanjut Usia Di Posyandu Serangan Desa Blusukan. Publikasi IImiah, Fakultas IImu Kesehatan, Universitas Muhammadiyah Surakarta.

Suharjana. 2013. Perbedaan Pengaruh Hasil Latihan Peregangan Statis dan Dinamis Terhadap Kelentukan Togok Menurut Jenis Kelamin Anak Kelas 3 dan 4 Sekolah Dasar.

Sullivan, K. O, Murray, E. Sainsburry, D. 2009. The Effect of Warm-Up, Static Stretching and Dynamic Stretching on Hamstring Flexibility in Previously Injured
Subjects. BMC Musculoskletal Disorders.

Susilo, D. A. 2014. Pengaruh Latihan Kelentukan Statis terhadap Peningkatan Fleksibilitas Punggung pada Siswa Kelas VIII SMP Negeri 1 Rejotangan. Skripsi, Fakultas IImu Keolahragaan, Universitas Negeri Malang.

Wiguna, P. D. A., Muliarta, I. M., Wibawa, A., Adiputra, L. M. I. S. $\mathrm{H}$. Intervensi Contract Relax Stretching Direct Lebih Baik Dalam Meningkatkan Fleksibilitas otot Hamstring Dibandingkan Dengan Intervensi Contract Relax Stretching Inderect pada Mahasiswa Program Studi Fisioterapi Fakultas Kedokteran Universitas Udayana. 